San Jose State University

SJSU ScholarWorks

Master's Theses

Master's Theses and Graduate Research

1989

\title{
Differences between front-line foremen and their managers in perceptions regarding foreman training needs
}

Ronnie L. De La Cruz

San Jose State University

Follow this and additional works at: https://scholarworks.sjsu.edu/etd_theses

\section{Recommended Citation}

De La Cruz, Ronnie L., "Differences between front-line foremen and their managers in perceptions regarding foreman training needs" (1989). Master's Theses. 3133.

DOI: https://doi.org/10.31979/etd.y57s-pqap

https://scholarworks.sjsu.edu/etd_theses/3133

This Thesis is brought to you for free and open access by the Master's Theses and Graduate Research at SJSU ScholarWorks. It has been accepted for inclusion in Master's Theses by an authorized administrator of SJSU ScholarWorks. For more information, please contact scholarworks@sjsu.edu. 


\section{INFORMATION TO USERS}

The most advanced technology has been used to photograph and reproduce this manuscript from the microfilm master. UMI films the text directly from the original or copy submitted. Thus, some thesis and dissertation copies are in typewriter face, while others may be from any type of computer printer.

The quality of this reproduction is dependent upon the quality of the copy submitted. Broken or indistinct print, colored or poor quality illustrations and photographs, print bleedthrough, substandard margins, and improper alignment can adversely affect reproduction.

In the unlikely event that the author did not send UMI a complete manuscript and there are missing pages, these will be noted. Also, if unauthorized copyright material had to be removed, a note will indicate the deletion.

Oversize materials (e.g., maps, drawings, charts) are reproduced by sectioning the original, beginning at the upper left-hand corner and continuing from left to right in equal sections with small overlaps. Each original is also photographed in one exposure and is included in reduced form at the back of the book. These are also available as one exposure on a standard $35 \mathrm{~mm}$ slide or as a $17^{\prime \prime} \times 23^{\prime \prime}$ black and white photographic print for an additional charge.

Photographs included in the original manuscript have been reproduced xerographically in this copy. Higher quality $6^{\prime \prime} \times 9^{\prime \prime}$ black and white photographic prints are available for any photographs or illustrations appearing in this copy for an additional charge. Contact UMI directly to order.

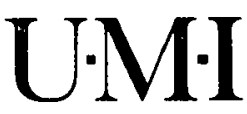

University Microfilms International

A Bell \& Howell Information Company

300 North Zeeb Road, Ann Arbor, MI 48106-1346 USA

$313 / 761-4700 \quad 800 / 521-0600$ 
Order Number 1338686

Differences between front-line foremen and their managers in perceptions regarding foreman training needs

De La Cruz, Ronnie L., M.A.

San Jose State University, 1989 

DIFFERENCES BETWEEN FRONT-LINE FOREMEN AND THEIR MANAGERS

IN PERCEPTIONS REGARDING FOREMAN TRAINING NEEDS

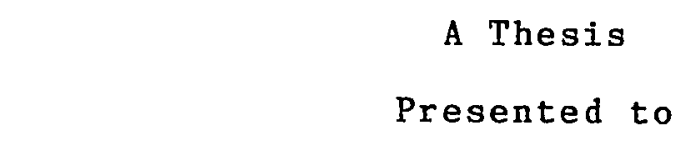

The Faculty of the Department of Psychology

San Jose State University

In Partial Fulfillment

of the Requirements for the Degree

Masters of Arts

\author{
by \\ Ronnie L. De La Cruz \\ December, 1989
}


APPROVED FOR THE DEPARTMENT OF PSYCHOLOGY
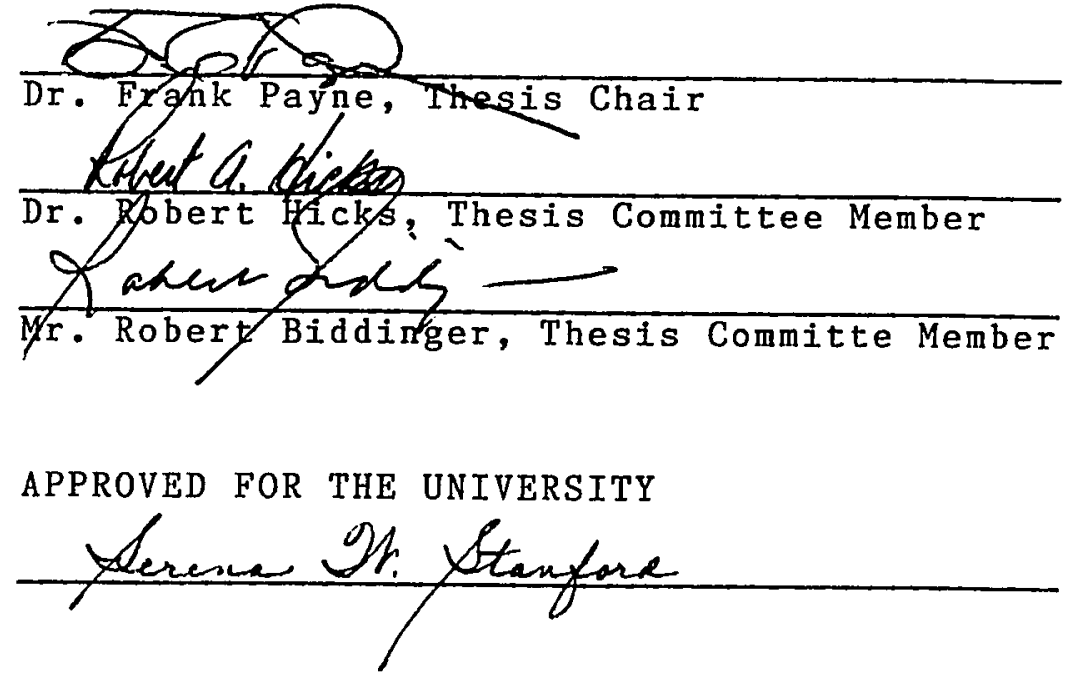
ABSTRACT

DIFFERENCES BETWEEN FRONT-LINE FOREMEN AND THEIR MANAGERS

IN THEIR PERCEPTIONS REGARDING FOREMAN TRAINING NEEDS

by Ronnie L. De La Cruz

This thesis addresses foreman training needs in an agricultural business setting. It examines the differences in perceptions between foremen and their managers in regards to the training needs of the foremen. As foremen training programs are often designed and implemented by managers, it is important that the manager accurately appraise his foreman's needs.

This research confirms earlier studies in which significant differences were found between foremen and managers when rating foreman training needs. In this study foremen rated their need for training in clerical skills as their highest priority while their managers rated the foreman's need for training in organizing work as the top priority. Not only must foremen be included in the design of their training programs so that the appropriate training needs are addressed, but the foreman's involvement and ownership in the design of the training program further assures the training program's success. 


\section{ACKNOWLEDGEMENTS}

There are several people; without whose help and support the completion of this thesis would not have been possible. First, I'd like to acknowledge the constant support of my wife Janne. The completion of this thesis is as much a credit to her endurance as it is of mine. Secondly I'd like to express my gratitude to Dr. Frank Payne and Dr. Robert Hicks of San Jose State University. Both were instrumental in my acceptance into a grant program at San Jose State which made it possible for me to pursue my college education. Both Doctors Payne and Hicks have contributed immensely in the successful completion of my Master of Arts Degree.

Finally, I'd like to thank the National Institute of Mental Health for funding the Minority Access to Research Careers program at San Jose State University. Without this funding I would not have been able to pursue my education beyond the Communty College level. 
TABLE OF CONTENTS

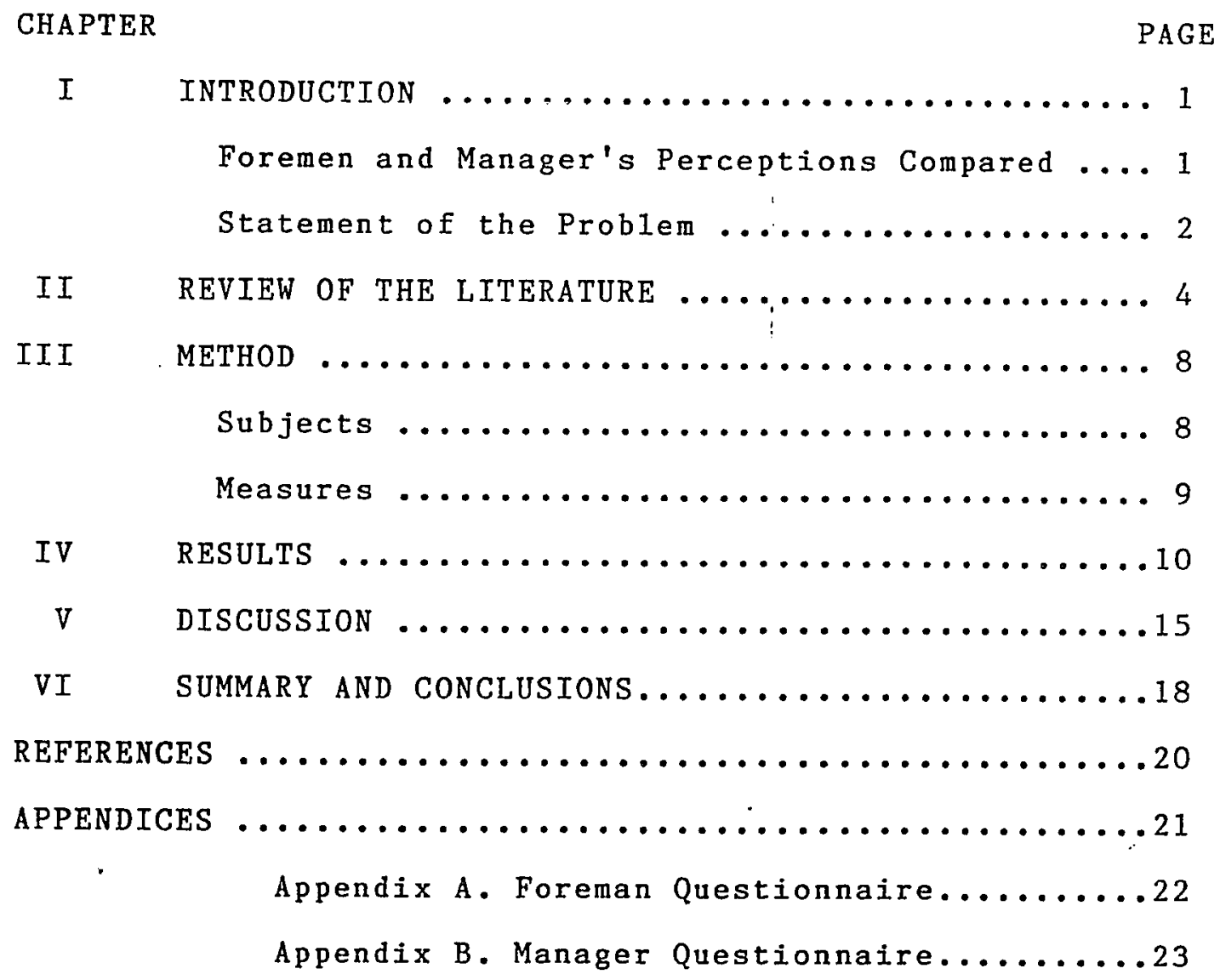


LIST OF TABLES

TABLE

PAGE

1. Means, Standard Deviations, $t$ Scores and Proportion of variance accounted for in Foreman Training Needs Between Foremen and Their Managers .............. 10 


\section{LIST OF FIGURES}

FIGURE

1. Frequency Distribution of the Manager's and Foreman's Ratings of the Foreman's Need for Training on the Union Contract ........... 11

2. Frequency Distribution of the Manager's and Foremen's Ratings of their Need for Training on the Planning and Organizing Skills ......

3. Frequency Distribution of the Manager's and Foreman's Ratings of the Foreman's Need for Training on Clerical Skills ............. 1 
CHAPTER I

INTRODUCTION

Foremen and Manager's Perceptions Compared

The early industrial foreman had a "bull of the woods" image and was generally feared, yet respected, by those who worked for him. As technological and sociological changes took place, organizations became gigantic bureaucratic institutions laced with specialized personnel (Cook, 1981). Additionally, with the passage of the labor legislation of the 1930's, unions became a significant balance of power against management. With these changes, the foreman's authority, power, and status have steadily declined (Barnard, $1984)$.

Currently, the foreman often finds himself sandwiched among the often conflicting interests of mangement, the union, the hourly worker, the staff specialist and his peers. Add to this the need for the foreman to master ever increasing levels of technology and you paint a picture of a position which commands relatively 1 ittle respect, authority, or support. Given all this, we should not find it at all surprising that recent research suggests that today's foremen are easily frustrated as they attempt to execute their daily charge. In addition to having a negative effect on foremen, there are also negative implications for the entire organization. For example, Schoenfeldt's research (1984) 
substantiates previous findings which indicate that job dissatisfaction among foremen can have negative physiological and psychological effects that can lead to dysfunctional organizational behavior and poor job performance. Statement of the Problem

One aspect of training that the literature appears to agree on is that a thorough foremen training program begins with a comprehensive needs analysis. As Friedman and Yarbough (1985) state, "The first step is to sort the problems from the nonproblems." Only following a thorough needs analysis can a comprehensive training program be designed and implemented. The specific issues to be dealt with in this study are:

What do foremen think they need in the way of training?

- What do managers think foremen need in the way of training?

Hypothesis 1. The mean rating by managers and foremen of foremen training needs in six specific skill areas will be significantly different.

The a priori reason for anticipating differences in perceptions between foremen and their managers regarding foreman training needs centers on the findings of Lampe (1986), which found that foremen and their managers did not 
agree what it is the foremen require training on or the degree of training needed. 
CHAPTER II

SURVEY OF RELATED LITERATURE

Today's modern corporation envisions itself as a finely tuned, efficient system based on sophisticated information networks coupled with well educated, highly motivated management. The issue now becomes one of updating the skills and attitudes of the front-line foreman (Hubbard, 1968).

A review of the literature finds many diverse opinions regarding the goal of foreman training. Some researchers, such as Kaman (1985), see the successfully trained foreman as being able to better organize work, communicate instructions, follow through on instructions, discipline workers and reinforce behavior, as well as better able to accurately assess work performance and implement new ideas and policies. Deming (1982) defines the aim of supervision as improving the performance of man or machine to improve output and simultaneously to lighten the load of the production worker--"to help people to do a safer, better job with less effort" (p. 115). Juran (1985) defines training as that process which creates or updates skills and facilitates a change in attitude. Juran then continues on in his effort to further identify and clarify in detail the distinction between a change in attitude, which is a "state of mind," and a change in behavior, which is a "state of action." Although the goal of training is to change behavior, a 
change in attitude may facilitate a long-term change in behavior via an internal reinforcement mechanism.

In reviewing the literature it becomes quite clear that there are many diverse opinions regarding the specific goals of foreman training. However, in many situations the primary responsibility of the front line foreman is to maximize the output of quality products in the safest possible manner. To do this effectively, the foreman must not only be a problem solver, but must also possess the ability to implement solutions. In addition, good foremen must have good problem solving skills (including the ability to identify problems and their components), the ability to solicit input from both subordinates and upper management, the ability to apply "on the spot" decision-making skills (as well as effective implementation skills including effective planning and organizing of work schedules), and the ability to assign, follow up and evaluate subordinate performance. Add to all this, basic communication and motivational skills and in-depth knowledge of contractual and position limitations, and we find ourselves with an outline of basic foreman survival skills.

The particular problem to be addressed in this thesis is the development of a comprehensive needs analysis designed to identify the particular training needs of Mexican national 
foremen working for a large American agricultural firm. In general, the foremen in this firm have very low average educational levels, as well as unique motivational and instructional needs. Additionally, the Hispanic foreman is often suspicious of management intent and will most probably receive training with guarded defensiveness at best. In reviewing the current responsibilities and problem areas associated with the front-line foreman in the organization, it was clear that neither the foremen nor their managers had a clear understanding of what the foremen require in terms of training. Much of this is the result of a general disagreement or misunderstanding of what exactly the foreman's primary responsibilities are. Arthur Wallach (1977) found significant differences between the perceptions of managers versus foremen when both were asked to define the role of the foreman or provide a detailed job description of the foreman. In general, the foremen saw their authority being much more limited than did their respective managers. For example, most of the foremen reported a tendency to pass discipline matters on to their managers for fear that the manager might overturn the foreman's initial decision. Conversely, managers reported a general lack of aggressiveness, as well as a general reluctance on the part of the foremen when it came to effective management of 
discipline matters.

Once the organization has identified those areas in which training is required they can then develop the means most appropriate to updating the foremen' managerial skills. Although most of the foremen in this organization have held their position for more than five years, they have not received any formal training other than an occasional halfday seminar on broad subjects such as safety.

Once effective steps have been taken to identify those areas in which the foremen require training in better understanding of what it is that they are supposed to do and the skills to do the job effectively, but we must also provide continued accountability to ensure that the foremen make effective use of their updated skills (Henning, 1985). This of course is a separate issue which the management of this organization will have to address at a later time. 


\section{CHAPTER III}

METHOD

\section{Subjects}

All managers and foremen within the organization participated in the needs analysis. This included 26 foremen and their eight managers. The general manager of the facility and the investigator met with all foremen and managers to discuss the project and the potential benefits to the organization. They answered all questions raised by the participants. At the end of the informational portion of the meeting, each foreman and manager was given a one-page questionniare (Appendices $A$ and $B$ ) which was completed anonymously and dropped into a locked box at the end of the session.

- Of the eight managers, six had been in their current position in excess of five years and the other two had a minimum of three years in their current position. In terms of education, all eight managers had a B.A. degree or higher. The average age of the eight managers was 38 years with a range between 29 and 52 .

of the 26 foremen, the average time in the current position was 4.3 years, with a range of 6 months to 11 years. In terms of education, 48 percent of the foremen had only an elementary education, with only eight percent having some 
college education. The average age of the foremen was 32 years, with a range between 26 and 58 .

Although participation in the needs analysis was mandatory, top management went to extreme lengths in selling the concept and the value of the generated data.

\section{Measures}

A questionnaire designed to assess the foreman's perceived need or perceived desire for training in each of six different management skill areas (Fitz-enz, 1984) was given to all managers and foremen within Monterey Mushrooms (see Appendix $A$ ), as outlined earlier. As recommended by Culberston and Thompson (1980), the questionnaire was designed to progress from general questions to more specific questions to allow the participants to become comfortable with the process. The first section of the questionniare was designed to collect background information such as age, bilingual skills, number of years employed at Monterey Mushrooms, and whether the individual was promoted to the position of foreman from general worker or from the union. Additional questions included the amount of time in the position of foreman at Monterey Mushrooms and previous experience. The second section of the questionnaire asked the participants to rate the need or desire of foremen for training in each of six skill areas. 
CHAPTER IV

RESULTS

Skewness and Kurtosis values were calculated for each of

the six skill areas. All values were well below generally acceptable levels and did not indicate any irregulariiies in the respective distributions. The means, standard deviations, $t$ scores, and proportion of variance accounted for are presented in Table 1.

Table 1

Means, Standard Deviations, and $t$ values for Perceptions in Foreman Training Needs Between Foremen and Their Managers.

\begin{tabular}{|c|c|c|c|c|c|}
\hline Skill Area & $\underline{M}$ & $S D$ & & $\underline{t}$ & $r^{2}$ \\
\hline $\begin{array}{r}\text { Contract Knowledge } \\
\text { Managers } \\
\text { Foremen }\end{array}$ & $\begin{array}{l}3.75 \\
4.14\end{array}$ & $\begin{array}{l}.66 \\
.84\end{array}$ & $\underline{t}=$ & $1.18, \mathrm{p}>.05$ & - \\
\hline $\begin{array}{c}\text { Planning \& Organizing } \\
\text { Managers } \\
\text { Foremen }\end{array}$ & $\begin{array}{l}4.06 \\
3.14\end{array}$ & $\begin{array}{l}.68 \\
.79\end{array}$ & $\underline{t}=$ & $2.98, \mathrm{p}<.01$ & .22 \\
\hline $\begin{array}{c}\text { Clerical Skills } \\
\text { Managers } \\
\text { Foremen }\end{array}$ & $\begin{array}{l}3.19 \\
3.79\end{array}$ & $\begin{array}{l}.75 \\
.76\end{array}$ & $\underline{t}=$ & 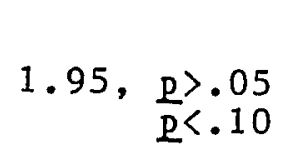 & .11 \\
\hline $\begin{array}{c}\text { Disciplinary Skills } \\
\text { Managers } \\
\text { Foremen }\end{array}$ & $\begin{array}{l}2.31 \\
2.44\end{array}$ & $\begin{array}{l}.75 \\
.86\end{array}$ & $\underline{\mathrm{t}}=$ & $.38, p>.05$ & - \\
\hline $\begin{array}{c}\text { Communication Skills } \\
\text { Managers } \\
\text { Foremen }\end{array}$ & $\begin{array}{l}2.13 \\
2.27\end{array}$ & $\begin{array}{r}.84 \\
.74\end{array}$ & $\underline{t}=$ & $.47, \mathrm{p}>.05$ & - \\
\hline $\begin{array}{c}\text { Motivational Skills } \\
\text { Managers } \\
\text { Foremen }\end{array}$ & $\begin{array}{l}3.44 \\
3.33\end{array}$ & $\begin{array}{l}.73 \\
.73\end{array}$ & $\underline{t}=$ & $.37, p>.05$ & - \\
\hline
\end{tabular}

Note: Degrees of freedom for all tests are 32 . 
Figure 1 illustrates the frequency distribution of the managers' and foremen ratings or perceptions regarding the foreman's need for training on the union contract. Managers and foremen tend to rate the need for training on the union contract as a fairly high need, although the foremen rated it slightly higher than did their managers. As indicated in Table 1, the difference was not statistically significant. \% of Sample

$100 \%$

$90 \%$

$80 \%$

$70 \%$

$60 \%$

$50 \%$

$40 \%$

$30 \%$

$20 \%$

$10 \%$

$0 \%$

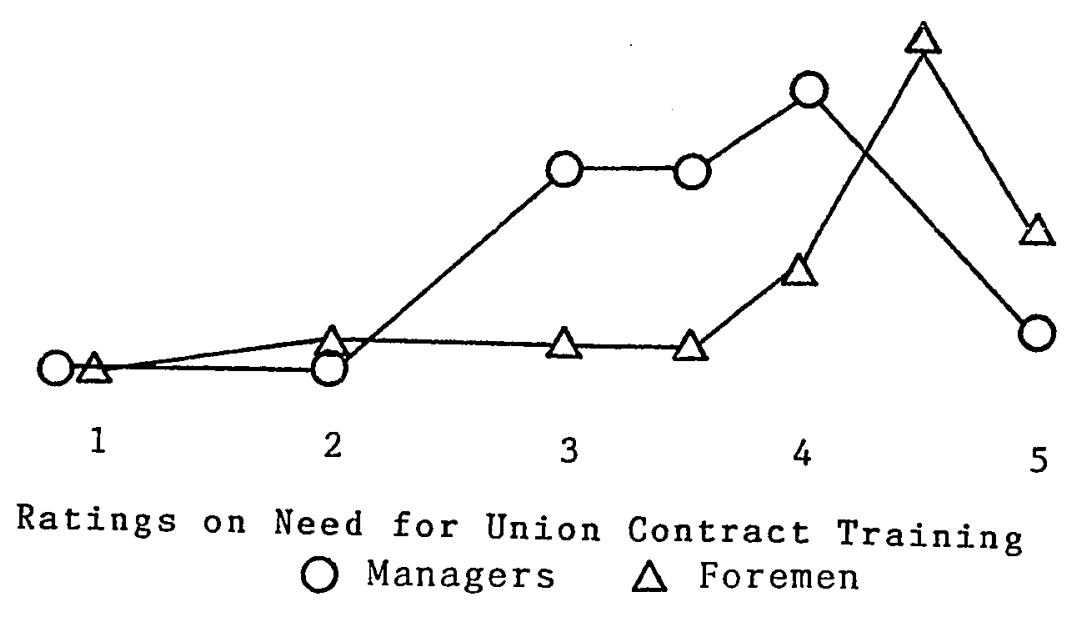

Figure 1

$\bigcirc$ Managers $\triangle$ Foremen

Frequency Distribution of Managers' and Foremen Ratings of their Need for Training on the Union Contract 
Figure 2 illustrates the frequency distribution of managers and foremen ratings of the foreman's need for training on organizing work. Managers rated this need significantly higher than did their foremen (see Table 1). Furthermore, as indicated in Table 1, group membership (Managers versus Foremen) accounted for $22 \%$ of the variance in this rating, emphasizing the substantial nature of the difference. $\%$ of Sample

$100 \%$

$90 \%$

$80 \%$

$70 \%$

$60 \%$

$50 \%$

$40 \%$

$30 \%$

$20 \%$

$10 \%$

$0 \%$

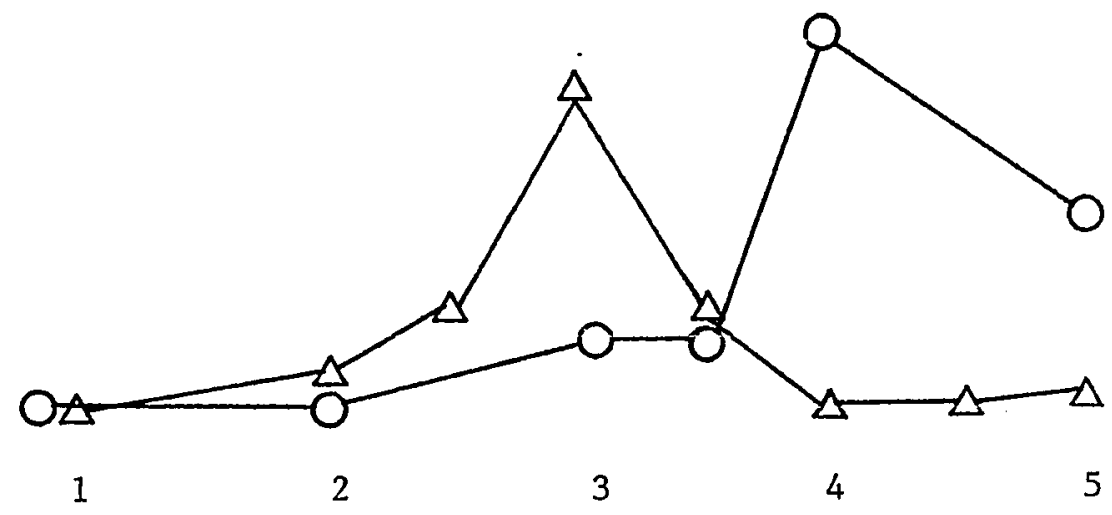

Ratings on Need for Training on Planning Skills

Figure 2

$$
\mathrm{O}=\text { Managers } \Delta=\text { Foremen }
$$

Frequency Distribution of Managers' and Foremen Ratings of their Need for Training on Planning and Organizing Skills 
Figure 3 presents the frequency distribution of the manager's and foremen ratings of the foreman's need for training on clerical skills. The foremen tended to rate their need for training on clerical skills higher than did their managers. Although the difference was not signifcant at the .05 level, it was significant at the .10 level, and it accounted for $11 \%$ of the variance in the ratings. $\%$ of Sample

$100 \%$

$90 \%$

$80 \%$

$70 \%$

$60 \%$

$50 \%$

$40 \%$

$30 \%$

$20 \%$

$10 \%$

$0 \%$

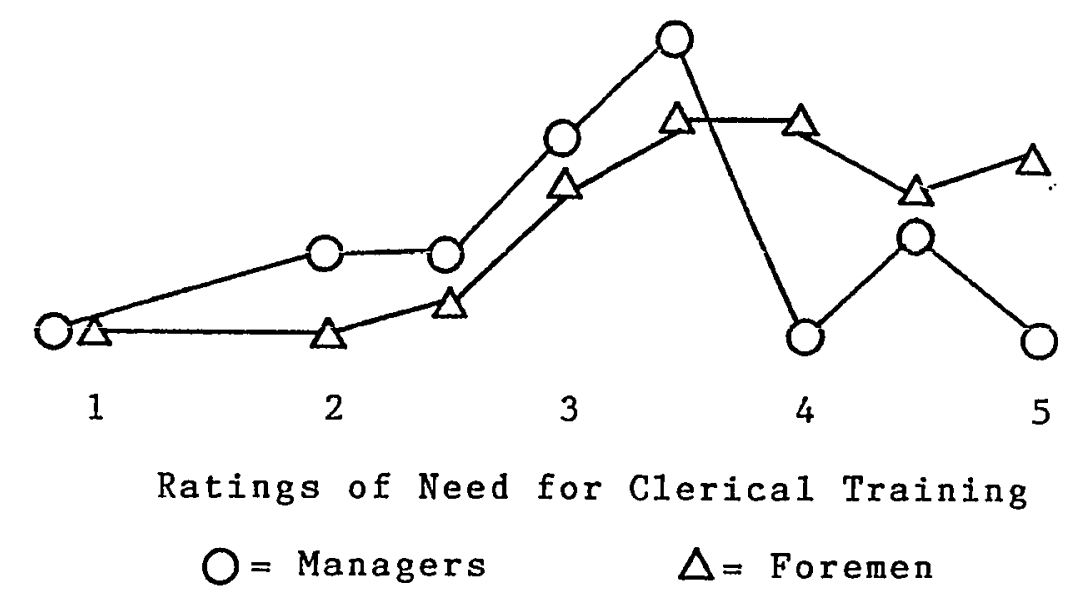

Figure 3

$$
\mathrm{O}=\text { Managers } \Delta=\text { Foremen }
$$

Frequency Distribution of Managers' and Foremen Ratings of their Need for Training on Clerical Skills 
As indicated in Table 1 , the managers and their foremen did not disagree significantly in regards to the amount of training required in the remaining three managerial areas: disciplinary, communication and motivational skills. In those skill areas considered more important by the managers, discipline and communication, the managers rated the need for foremen training slightly lower than did the foremen. This may suggest that the managers believe the foremen to be more effective and comfortable in these areas than the foremen actually are. The skill area of communication received the overall lowest rating by both foremen and managers. Finally, the foremen rated their need for training on motivational skills slightly lower than did their managers. 


\section{CHAPTER V}

\section{DISCUSSION}

The results of the comparisons between the foremen and managers' perceptions regarding foreman training needs were mixed. In general, the foremen and their managers were in agreement that some degree of training was required in each of the various six skill areas. However, detailed statistical analysis found that the foremen and their managers were only in agreement about the degree of training required in four of the six skill areas (union contract knowledge, disciplinary skills, communication skills and skills and motivational skills).

With regard to the first skill area, both foremen and managers rated the need for training on the union contract as a high need. This of course makes sense when you consider that a major component of the foreman's daily responsibility is the management of his crew. The union is a very strong force in this company and a lengthy union contract details the various steps and methods of discipline, as well as most other aspects of the daily management of the work force. In the case of this particular organization, management estimates that as much as 20 percent of the disciplinary actions initiated against union employees must be dropped because of improper procedure or documentation on the part of the foreman. Individual crew sizes can vary from 10 to 30 
employees and each crew has its own union representative. This representative is selected by majority vote within the crew and has the responsibility of representing the employees on behalf of the union. The crew's union representative is a considerable force with which the foreman must deal with in the daily management of his crew. It is particularly frustrating for the foreman when he takes disciplinary action against a union employee only to have the action dropped by his manager because the foreman failed to follow proper procedure. The foreman, believing he was right in his attempt to discipline the employee, feels that his manager has abandoned him in the face of union pressure. The manager is equally frustrated with the foreman's inability to follow proper procedures. It is therefore encouraging that that, both managers and foremen are in basic agreement regarding the foreman's need for training on the union contract as one of the highest needs of the six different ski11 areas.

It is perhaps, also encouraging, that the two groups basically agreed on the last three skill areas: disciplinary skills (area 4), comunication skills (area 5), and motivational skills (area 6). In the first two of these, both managers and foremen agreed that disciplinary skills and communication skills were of relatively low importance in 
terms of need for training. They also agreed closely that need for training in motivational skills was of more moderate importance.

On the other hand, the foremen and their managers did not agree on the degree of training required on planning and organizing skills (area 2), as well as the need for training on clerical skills (area 3 ). In general, the managers rated the foreman's need for training on planning work higher than did the foremen, while the foremen in general rated their need for training on clerical skills as their second highest need. It is interesting to note that a great deal of the foreman's disorganization, as perceived by the managers, is possibly due to the foreman's inability to effectively deal with all the required paper work. This may account for the foreman's higher rating of clerical training. 
CHAPTER VI

\section{SUMMARY AND CONCLUSIONS}

Although somewhat mixed, the results of this study tend to confirm the previous findings of Lampe (1986) in that foremen and their managers do not always agree in their perceptions regarding foreman training needs. In this study I found that in some skill areas of today's front-line foreman, such as knowledge of the union contract, managers and foremen tend to agree in their perceptions regarding the amount of training the foreman requires. In the case of knowledge of the union contract it might appear relatively easy to identify those aspects of the foreman's daily responsibilites which are affected by this skill area. However, many of the continuing problems experienced by the foremen in dealing with the union are compounded by their inability to effectively handle the increasing amounts of paper work and documentation demanded by both the union and management. Thus some of the problems that the managers attribute to a lack of knowledge or understanding of the union contract on the foreman's part, may, in fact, be part of the foreman's reported difficulties in clerical skills. This reinforces the need to collect information regarding training needs from both the managers and foremen. In the case of this organization, as possibly with others, the foreman training program was originally to be 
designed by the upper management group, which unfortunately did not include the foremen. In this case the managers would probably have mistaken their perceptions as representative of the foremen. If the managers had determined the content of the foreman training program, a critical element such as training in clerical skills could have been overlooked. Additionally, by allowing the foremen to become actively involved in determining the content of "their" training program the organization increased the chances of a successful training effort. With a sense of ownership in the design of the program, the foremen had a vested interest in the success of the training venture.

Continued research on properly identifying foreman training needs will hopefully provide valuable information that can be utilized by organizations as an initial step in the development of their training programs. It is essential that management include those individuals who are to benefit from training as they sort the problems from the non-problems.

It is gracifying to know that this organization intends to utilize the data collected from this study in the design of their foreman training program. 
. 
Barnard, J. (1984). The foreman's role in the new Journal, 93, Society for Advancement of Management Cook, D. (1981). Where theory collides with reality.
Industry Week, $45,75-80$.

Culberston, K., \& Thompson, M. (1980). An analysis of supervisory training needs. Training and Development
Journal, $81,58-62$.

Deming, E. (1982). Quality, Productivity, and Competetive Position. Cambridge: Massachusetts Institute of

Fitz-enz Management. $(1984)$ New York: McGraw-Hill.

Friedman, P., \& Yarbrough, E. (1985). Training Strategies From Start to Finish. New Jersey: Prentice-Hall Inc.

Henning, J. (1985). The necessity of support systems. Training and Development Journa1, 73, 14 .

Hubbard, S. (1968). Supervisors: what they are taught and
what they real1y need. Journal of Management, 58, 24-26. Journal of Personnel and Training

Jurán, J. (1979) Quality Control Handbook. (3rded.). New
York: McGraw-Hill.

\begin{tabular}{l} 
Kaman, V. \\
Journal, \\
\hline $96,42-47$
\end{tabular}

Lampe, S. (1986, October). Getting the Most Out of Needs Assessments. Training The Magazine of Human Resources
Development, pp. $101-104$.

Schoenfeldt, R. (1983). The foreman: is his job as bad as
they say? 12-17.

Wallach, A. $(1977)$. The man in the middle. Personnel
Journal, $61,622-623$. 
:

APPENDICES 
APPENDIX A

MONTEREY MUSHROOMS FOREMAN TRAINING PROJECT

(Needs Analysis, Foreman Questionnaire)

1. a) How long have you been employed at Monterey Mushrooms?

Years Months

b) How long have you been a Foreman with Monterey Mushrooms?

Years - Months
Did you have any previous experience in the position
of Foreman or supervisor before coming to Monterey?
Yes

d) Are you bilingual?

Yes 느는 No

2. Were you a general worker with Monterey Mushrooms

prior to being promoted to a foreman?

3. On average, how many workers are in your crew?

4. Please rate your need or desire for training in each of the following six skill areas ( $1=1$ ittle or no need/desire to $5=$ a lot of need or desire).

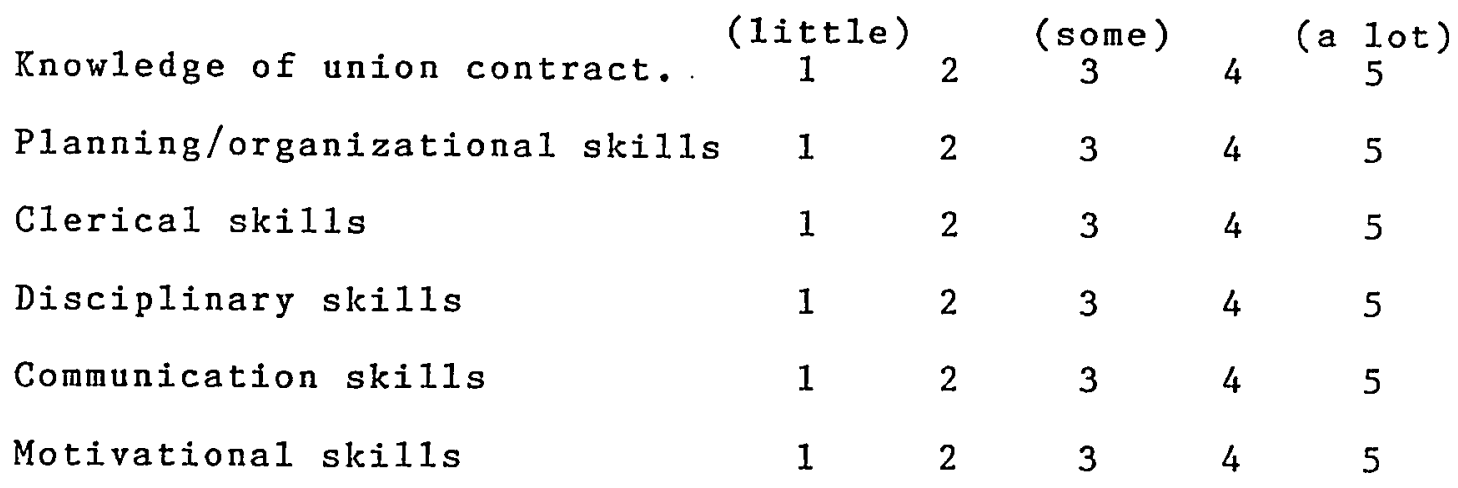

Thank you fo- your cooperation 
APPENDIX B

MONTEREY MUSHROOMS FOREMAN TRAINING PROJECT

(Needs Analysis, Manager Questionnaire)

1. a) How long have you been employed at Monterey Mushrooms?

Years Months b) How long have you been a Manager with Monterey
Mushrooms?

Years Months

c) Did you have any previous experience in the position of Manager before coming to Monterey Mushrooms?

Yes No If yes, how many years

d) Are you bilingual?

Yes No

2. Were you a foreman or supervisor with Monterey Mushrooms prior to being promoted to a manager?

3. On average, how many workers are in your dept.?

4. Please rate your foremen' need or desire for training in each of the following six skill areas ( $1=1$ ittle or no need/desire to $5=a$ lot of need or desire).

$\begin{array}{lccccc}\text { Knowledge of union contract. } & \text { (1ittle) } & 1 & \text { (some) } & \text { (a } 10 t \text { ) } \\ \text { Planning/organizational skills } & 1 & 2 & 3 & 4 & 5 \\ \text { Clerical skills } & 1 & 2 & 3 & 4 & 5 \\ \text { Disciplinary skills } & 1 & 2 & 3 & 4 & 5 \\ \text { Communication skills } & 1 & 2 & 3 & 4 & 5 \\ \text { Motivational skills } & 1 & 2 & 3 & 4 & 5\end{array}$

Thank you for your cooperation 